\title{
SEPARATING THE WHEAT FROM THE CHAFF: DELIMITING PUBLIC POLICY INFLUENCE ON THE ARBITRABILITY OF DISPUTES IN AFRICA
}

\author{
Akinwumi Ogunranti*
}

\begin{abstract}
This article focuses on the arbitrability of disputes. It examines the recent global trend of delimiting the role of public policy in determining matters that should be subject to arbitration. The evaluation shows that the application of doctrines of separability and kompetenz-kompentenz plays a vital role in the delimitation process. However, notwithstanding the global trend to restrict the role of public policy in determining arbitrability, some countries in Africa still widely interpret public policy to revoke arbitral clause, stay arbitral proceedings, or refuse enforcement of foreign arbitral awards. They justify this approach on the basis that public policy is a means to protect national economic interest against foreign manipulation or exploitation. Anchored on Morgan's theoretical approach, this article criticizes the excessive role of public policy in determining the arbitrability of disputes in Africa. It calls for a change to reflect the global trend through judicial activism and legislative reform. Although protecting national economic interest is an important goal, restricting matters that are arbitrable will not promote foreign investment. Therefore, countries in Africa must fashion arbitration practices that reflect their socio-economic background as well as contemporary arbitral trends around the world.
\end{abstract}

Keywords: Arbitration; Africa; Party Autonomy; Public Policy

DOI: https://dx.doi.org/10.4314/jsdlp.v10i1.6

\section{INTRODUCTION}

Party autonomy includes the right of contractual parties to choose an adjudicatory forum to determine rights and obligations arising from

* Doctoral Student, Schulich School of Law, Dalhousie University, Halifax, Nova Scotia, Canada. Email: ak950986@dal.ca. 
their legal relationship. To this end, parties in most jurisdictions have the autonomy to decide whether to determine their legal rights in a national court or an arbitration tribunal. However, this right is usually limited to private claims between individuals. Public claims are deemed non-arbitrable because they involve matters considered to affect the larger society. ${ }^{1}$ This limitation, which is decided by states according to their social and economic policy, generally defines arbitrable matters. ${ }^{2}$

Arbitrability has two meanings. ${ }^{3}$ First, its sense as objective arbitrability refers to the permission granted by the state for a dispute to be settled by arbitration rather than courts. ${ }^{4}$ Second, it refers to the sufficient jurisdiction of the arbitral panel to settle a dispute based on the construction of the arbitration clause - subjective arbitrability. ${ }^{5}$ This article focuses on the first definition from an international commercial arbitration perspective. It argues that the influence of public policy should be limited in the determination of arbitrability in Africa, especially in international commercial disputes.

Scholars have examined the scope of arbitrable matters in international commercial arbitration. ${ }^{6}$ Early writers on this subject support a wide interpretation of national public policy to deny an

1 See Klára Drlièková, "Arbitrability and Public Interest in International Commercial Arbitration" (2017) 17 ICLR 55, 58-60 for analysis on why some cases are adjudged non-arbitrable.

2 Alan Redfern and Martin Hunter, Law and practice of International Commercial Arbitration (Sweet \& Maxwell 1991), p.137.

3 The definition is based on classifications of arbitrability because there is no single legal instrument that gives a succinct definition of the concept. Nyanchoka notes that "There is no unified international concept of arbitrability". He, however, adopts the objective classification of arbitrability when he noted that "Loosely, the concept has been defined in a limited manner to mean whether specific clauses of disputes are barred from arbitration because of national legislation or judicial authority". See Alfred Nyanchoka, "The Scope of Arbitrability Under Kenyan Law" (2013) 79 Arbitration 273, 273.

4 This is referred to as objective arbitrability. See Piero Bernardini, "The Problem of Arbitrability in General" in Emmanuel Gaillard \& Domenico Di Pietro (eds), Enforcement of Arbitration Agreements and International Arbitration Awards: The New York Convention in Practice (Cameron May 2008) 503. See also, Natalja Freimane, "Arbitrability: Problematic Issues of the Legal Term" (LLM, Riga Graduate School of Law 2012) 22.

5 See Ilias Bantekas, "The Foundations of Arbitrability in International Commercial Arbitration" (2008) 27 Australian Year Book 193, 193.

6 See for example, Karl-Heinz Böckstiegel, K., "Public Policy and Arbitrability" in Peter Sanders P (ed), Comparative Arbitration Practice and Public Policy in Arbitration, No 3 (Kluwer 1987) 177; Bernard Hanotiau \& Olivier Caprasse, 
extended scope for arbitrable matters because, in their view, arbitrators do not possess the competence and skill to handle matters that border on public policy. ${ }^{7}$ However, recent comments on this subject admit the need to narrowly interpret national public policy to permit a wider scope of arbitrable matters in order to attract foreign investors and create a "friendly arbitration country". ${ }^{8}$ Some scholars even argue that national public policies should be abandoned altogether for a transnational public policy. ${ }^{9}$ However, there is a dearth of literature on this subject from an African perspective. Few scholars focus on the problems of arbitrability and when they do, they do not provide any likely solution to the issue of public policy influence on arbitrability. ${ }^{10}$ They predominantly tried to comparatively show the disparity between the influence of public policy on arbitrability in other jurisdictions and Africa without suggesting ways to bridge the gap. ${ }^{11}$

This article seeks to fill the vacuum in the literature by demonstrating how the interpretational approach in some countries, recognized as desired arbitral seats, reflects a sound economic response to globalization. It discusses the need for a similar approach for African countries, especially Nigeria.

This article is divided into six sections. Section 2 examines the amorphous nature of public policy and argues that the inability of

"Arbitrability, Due Process and Public Policy Under Article V of the New York Convention: Belgian and French Perspectives" (2008) 25 Journal of International Arbitration 721.

7 See Thomas Carbonneau \& Andrew Sheldrick, "Tax Liability and Inarbitrability in International Commercial Arbitration" (1992) 1 Journal of Transnational Law and Public Policy 23, pp. 31-35.

8 See Rushmi Sethi, "International Arbitration: The Jurisdictional Award in Philip Morris v Uruguay, and Enforcement of Arbitration Awards" (2016) 32 Arbitrational International 535, 540. But see Robert French, "Arbitration and Public Policy" (2016) 24 Asian Pacific Law Review 1, 15 (He argues that public policy should not only be about attracting business).

9 See, for example, Pierre Lalive, "Transnational (or Truly International) Public Policy and International Arbitration" in Peter Sanders P (ed), Comparative Arbitration Practice and Public Policy in Arbitration, No 3 (Kluwer 1987), p. 258.

10 See, for example, Amazu Asouzu, International Commercial Arbitration and African States: Practice, Participation and Institutional Development (Cambridge University Press 2001).

11 Joseph Mante \& Issaka Ndekugri, "Arbitrability in the Context of Ghana's New Arbitration Law" (2012) 15 International Arbitration Law Review 31; Joseph Mante, "Arbitrability and Public Policy: An African perspective" (2016) 33 Arbitration International 1. 
courts and scholars to universally define this term is a reason for its divergent influence on arbitrability. Section 3 notes that notwithstanding the amorphous nature of public policy, most countries, especially developed ones, have limited public policy influence in the determination of arbitral disputes. Section 4 shows a contrary approach in some African countries. Through the analysis of case studies in Nigeria, Uganda, and Ghana, this section demonstrates how some African countries restrict matters that are arbitrable because of their wide interpretation of public policy. It subjects these cases to theoretical analysis and argues that they fail to distinguish between those rights that naturally flow from one person's interaction with another and those that are imposed by the state in furtherance of the collective interest. Section 5 argues for a change in approach from nationalistic protectionism to economic and investment promotion. If African countries will become an arbitration hub, they must fashion arbitration practices that reflect their socio-economic backgrounds, as well as contemporary global arbitral trends. Section 6 concludes that, given the amorphous nature of public policy, judicial activism is the most potent tool by which to enhance the prospect of a global convergence on arbitrability.

\section{DETERMINING ARBITRABILITY}

The determination of matters that are arbitrable is usually controversial. ${ }^{12}$ This controversy arises from the role that public policy plays in determining arbitrability. Public policy has not lent itself to easy definition, partly because it has no source of reference, and because it changes from time to time. In fact, Burrough J. says it is "a very unruly horse, and once you get astride it, you never know where it will carry you". ${ }^{13}$ Though difficult to define, public policy is usually expressed

12 See Mante (n 11). Indeed, it has been noted that " $[\mathrm{t}]$ he extent and nature of judicial intervention in the arbitral process has been an intense tussle between the contractual and jurisdictional theories of arbitration and would continue to be". See Asouzu (n 10) 176.

13 Richardson $v$ Mellish [1824] 2 Bing 229. See analysis of the doctrine of public policy in Bradon Kain \& Douglas Yoshida, "The Doctrine of Public Policy in Canadian Contract Law" [2007] Annual Review of Civil Litigation 1, 2-5 $<$ www.mccarthy.ca/pubs/The_Doctrine_of_Public_Policy_in_Canadian_ Contract_Law.pdf $>$ accessed on 18 August 2018. 
in four categories - mandatory law, fundamental principles of law, public order, or good morals and national interest. ${ }^{14}$ Notwithstanding this classification, the definition of public policy is yet to be globally agreed upon. Therefore, to determine matters that are arbitrable, there is no universally accepted distinction between public and private matters an unpleasant situation in international commercial arbitration. This difficult distinction between private and public matters is exacerbated by two international commercial arbitration instruments which neither define public policy nor matters that are arbitrable. ${ }^{15}$

Article 1(5) of the United Nations Commission on International Trade Model Law on International Commercial Arbitration provides: "[t]his Law shall not affect any other law of this State by virtue of which certain disputes may not be submitted to arbitration or may be submitted to arbitration only according to provisions other than those of this Law". ${ }^{16}$ In effect, it permits states to decide issues of arbitrability and the role that public policy plays in it. Also, article $\mathrm{V}(2)$ (a) and V(2)(b) of the Convention on the Recognition and Enforcement of Foreign Arbitral Awards leaves the yardstick for determining public policy to each national court. ${ }^{17}$ Paragraph V(2)(a) provides that states could refuse enforcement on an award because it is non-arbitrable, while paragraph $\mathrm{V}(2)$ (b) provides that awards may not be generally recognized if they are against national public policy. ${ }^{18}$ In effect, matters that fall within the realm of public policy are, by nature, undefined. As well, instruments that regulate arbitration practice do not limit public policy matters. Therefore, the definition and application of public policy depend largely on courts' creativity.

\section{RECENT TRENDS IN ARBITRABILITY}

Over the years, most jurisdictions, especially developed countries that are considered as desired seats of arbitration, have widened the scope

14 Mante (n 11) 16.

15 For further analysis, see Homayoon Arfazadeh, "Arbitrability under the New York Convention: The Lex Fori Revisited" (2001) 17 Arbitration International 73.

16 United Nations General Assembly Resolution 40/72 (11 December 1985) amended in 2006 [the Model Law].

17 Convention on the Recognition and Enforcement of Foreign Arbitral Awards (10 June 1958) 330 UNTS 38 (New York Convention).

18 See also Article 34(2) (b) of the Model Law. 
of arbitrable matters. ${ }^{19}$ In other words, notwithstanding the absence of a universal definition of public policy, they have restricted the influence of public policy in determining arbitrability. ${ }^{20}$ The restriction becomes necessary to encourage parties to choose these countries as seats of arbitration and to promote foreign investment. ${ }^{21}$ In effect, globalization of international trade has necessitated considerable expansion of the scope of arbitrable matters in international commercial arbitration. Brief examples of how courts in some countries have restricted public policy influence on arbitrability will illustrate this point.

The United States' Supreme Court in Mitsubishi v. Soler ChryslerPlymouth, Inc ${ }^{22}$ held that courts should not "subordinate domestic notions of arbitrability to the international policy favouring commercial arbitration". ${ }^{23}$ Therefore, the "public policy defence is to be construed narrowly for application only where enforcement would violate the [United States'] most basic notions of morality and justice." ${ }^{24}$ Similarly, Canada's Supreme Court decision in Beals $v$ Saldanh ${ }^{25}$ narrowly applied public policy to only acts that offend Canadian principles of justice

19 See Queen Mary University of London \& White \& Case LLP, “2018 International Arbitration Survey: The Evolution of International Arbitration" <http:// arbitration.qmul.ac.uk/media/arbitration/docs/2018-International-ArbitrationSurvey - The-Evolution-of-International-Arbitration-(2).PDF $>$ accessed on 18 August 2018.The survey listed London, Paris, Singapore, Hong Kong and Geneva as the top five arbitration seats in the world.

20 See Karim Youssef, "The Death of Inarbitrability", in Loukas Mistelis \& Stavros Brekoulakis (eds), Arbitrability: International and Comparative Perspective (Kluwer 2009), p.57.

21 See Freimane (n 4), p.16.

22105 S Ct 3346 (1985). It positively answered the question of whether a properly constituted arbitral body pursuant to a valid arbitration clause under the auspices of the New York Convention could adjudicate matters related to competition and antitrust law.

23 ibid 639. The court stated that "We conclude that concerns of international comity, respect for the capacities of foreign and transnational tribunals, and sensitivity to the need of the international commercial system for predictability in the resolution of disputes require that we enforce the parties' agreement, even assuming that a contrary result would be forthcoming in a domestic context". See also Christoph Liebscher, "Arbitration of Antitrust Disputes" in General' in Emmanuel Gaillard \& Domenico Di Pietro (eds), Enforcement of Arbitration Agreements and International Arbitration Awards: The New York Convention in Practice (Cameron May 2008), p.523.

24 Belize Bank Ltd v Gov't of Belize 191 F Supp 3d 26, 32, 39 (DDC 2016).

25 [2003] 3 SCR 416, 419. 
and fairness in a fundamental way. ${ }^{26}$ Also, under English law, all disputes concerning legal rights which can be the subject of an award are arbitrable. ${ }^{27}$ Therefore, English courts have held that competition or anti-trust claims that contain a public element are arbitrable. ${ }^{28}$ The New Zealand Arbitration Act 1996 also provides that an award is contrary to public policy only if "[a] breach of the rules of natural justice occurred - (i) during the arbitral proceedings; or (ii) in connection with the making of the award." ${ }^{29}$ Other countries like Singapore, ${ }^{30}$ that had previously widely interpreted public policy, now adopt a narrow approach. ${ }^{31}$ Also, a common trend in Europe, for instance, Austria, Belgium, Croatia, Cyprus, the Czech Republic, Estonia, and Finland, is that all disputes capable of private settlement are

26 See also the Ontario court decision in Schreter $v$ Gasmac, Inc (1992) 7 OR 3d 608, 621.

27 Michael Mustill, Baron Mustill \& Stewart Boyd, Commercial Arbitartion (2nd ed, Butterworths 1989) 149. Also, section 1030 of the German Civil Code provides that "[a]ny claim involving an economic interest can be the subject of an arbitration agreement. An arbitration agreement concerning claims not involving an economic interest shall have legal effect to the extent that the parties are entitled to conclude a settlement on the issue in dispute."

28 Et Plus SA v Welter [2006] Lloyd's Rep 251, 264; Fulham Football Club (1987) Ltd $v$ Richards (2011) EWCA Civ 855, para 78. (English Ct. App.). See also Katarzyna Sadrak, "Arbitration Agreements and Actions for Antitrust Damages after the CDC Hydrogen Peroxide Judgment" (2017) 16 Yearbook of Anti-trust and Regulation Studies 77. He argues that anti-competition contracts are enforceable in the European Union.

29 Arbitration Act 1996, sch 1, s 34(6) (NZ).

30 AJU v AJT [2011]4 SLR 739; PT Asuransi Jasa Indonesia (Persero) v Dexia Bank SA [2007] 1 SLR(R)597. See also Matthew Shaw, "Singapore Court of Appeal: When are Company Disputes Arbitrable?" (International Arbitration Newsletter, 17 December 2017) <https://dlapiper.com/en/canada/insights/publications/ 2015/12/international-arbitration-newsletter-q4-2015/singapore-court-ofappeal/> accessed on 15 April 2019. Also, Article 177 of the Swiss Private International Law Act (Act), regarding international arbitration, provides that "any dispute of financial interest may be subject of an arbitration." Subsection 2 provides that "A state, or an enterprise held by, or an organization controlled by a state, which is party to an arbitration agreement, cannot invoke its own law in order to contest its capacity to arbitrate or the arbitrability of a dispute covered by the arbitration agreement".

31 For more details, see generally Mistelis \& Brekoulakis (n 20); Freimane, (n 4). See also George Bermann, (ed), Recognition and Enforcement of Foreign Arbitral Awards: The Interpretation and Application of the New York Convention by National Courts, vol 23 (Springer International 2017), pp. 55-58. 
arbitrable. ${ }^{32}$ Indeed, the Australian Federal Court decision in WDR Delaware Corporation $v$ Hydrox Holdings Pty Ltd extended arbitrable issues to winding-up proceedings involving contractual disputes between sole shareholders. ${ }^{33}$ In this case, the court acknowledges that there is no public interest in such contractual disputes, and hence bifurcated the contract disputes between shareholders and the general winding-up proceedings.

In effect, contractual disputes including tax, bankruptcy, family, intellectual property, are increasingly arbitrable in most developed countries because courts separate private contracts from matters that hitherto had been confined to the public policy realm. This approach promotes party autonomy and empowers arbitral tribunals to decide on complex issues. It also contributes to the recognition of some countries as desired seats of arbitration, which ultimately may increase economic growth and capital flow because parties would prefer these countries as seats of arbitration and/or enforcement of award.

\section{DIVERGENT APPROACHES IN SOME AFRICAN COUNTRIES}

Notwithstanding that the role of public policy has waned in most jurisdictions in Europe, Asia, and America, ${ }^{34}$ some countries in Africa

32 See Tony Cole et al, Legal Instrument and Practice of Arbitration in the EU, Study for the Juri Committee (Brussels, European Union 2014) 40-42 < http:// europarl.europa.eu/RegData/etudes/STUD/2015/509988/ IPOL_STU(2015)509988_EN.pdf $>$ accessed on 18 August 2018. See also Antoine Kirry, "Arbitrability: Current Trends in Europe" (1996) 12 Arbitration International, pp. 373, 374-379.

33 [2016] FCA 1164. See also Nicola v Ideal Image Development Corporation Incorporated [2009] FCA 1177. It has generally been noted that “...the approach of Australian courts to the issue of arbitrability is far from settled. However, on balance, it may be concluded that a slight bias exists in favour of the arbitrability of most disputes, subject to there not being a sufficient element of legitimate public interest in the subject matter". See Robert Kovacs, "A Transnational Approach to the Arbitrability of Insolvency Proceedings in International Arbitration" [2012] International Insolvency Institute 1, $62<$ https:// iiiglobal.org/sites/default/files/transnationalapproachtothearbitrability ofinsolvencyproceedingsininternationalarbitration.pdf $>$ accessed on 20 March 2019.

34 Indeed, courts in these continents have extended arbitrable matters to family disputes which have traditionally been non-arbitrable. See Wendy Kennett, "It's Arbitration, But Not as We Know It: Reflections on Family Law Dispute 
still widely interpret public policy to restrict matters that are arbitrable..$^{35}$ Indeed, it has been noted that "[f]or many developing countries the traditional view that public policy issues are not arbitrable still holds sway". ${ }^{36}$ Rycroft further notes that "[t]he relevance of public policy for the determination of arbitrability has declined in Europe and America and the majority of the cases involving public policy are now deemed arbitrable. On the contrary, public policy remains of great significance in Africa". ${ }^{37}$ It is, therefore, no gainsaying that African countries rely on the public policy defence to revoke arbitral clause, stay arbitral proceedings, or refuse enforcement of foreign arbitral awards. This trend stems from the distrust of arbitration tribunals, as well as national courts' protectionist approach. ${ }^{38}$ Historically, most developing countries distrust arbitration as an avenue to settle public claims because they are regarded as complicated for arbitrators. ${ }^{39}$ The argument is that allowing parties to arbitrate on public claims goes against the notion of sovereign dignity. ${ }^{40}$ Developing countries, therefore, fear that this unfettered choice will favour parties from industrialized countries because they can unilaterally influence an agreement that is against the developing country's public policy. ${ }^{41}$ Indeed, it has been noted that "this type of private justice [arbitration] inevitably ignores the legitimate regulatory interests of concerned states". ${ }^{42}$

Resolution" (2016) 30 International Journal of Law, Policy and The Family 1; Adesina Bello, "Arbitration as a Template for Resolving Family Disputes" (2018) 84 Arbitration 239.

35 It should be noted that some countries outside the African continent still widely interpret public policy. An example is India, see Arjit Oswal \& Balaji Sai Krishnan, "Public Policy as a Ground to Set Aside Arbitral Award in India" (2016) 32 Arbitration International 651.

36 Mante \& Ndekugri, (n 11) 10, 28. For example, they argue that Ghanaian law on arbitrability may be one of the most restrictive legal systems on arbitrability in the world.

37 Alan Rycroft, "The Development of Concept of Arbitrability - An International Comparison" (LLM, University of Cape Town 2016) 4.

38 Andrew Armfelt, "Avoiding the Arbitration Trap" Financial Times (London, 27 October 1992) 20, quoted in Asouzu (n 10), p. 429.

39 Beata Kozubovska, "Trends in Arbitrability" (2014) 1 Institute of Advanced Legal Studies Student Law Review 22, 23

40 Mistelis \& Brekoulakis, (n 20) 6.

41 ibid.

42 Ibid. 
Arbitrability has, therefore, generated commentaries from scholars in Africa. Debate on arbitrability of human rights, admiralty, ${ }^{43}$ intellectual property, agreement between shareholders and companies, and winding-up disputes are rife in developing countries. ${ }^{44}$ The majority view is that these subject matters should not be arbitrable. The argument is that developing countries should not decrease the range of non-arbitrable matters because of the financial power foreign investors hold. ${ }^{45}$ In effect, they support the present broad interpretation of public policy to protect national interests in Africa. However, not all scholars subscribe to this approach. ${ }^{46}$ One of these proposes that human rights claims should be arbitrable in Africa. ${ }^{47}$ This article takes the same view regarding the arbitrability of disputes. It suggests ways to achieve a wider range of arbitrable disputes in Africa.

I argue that the protectionist approach advanced by scholars and national courts has negative effects on the growth of arbitration and economy in Africa because parties would not choose African countries as the seat of their arbitration. This is because the restrictive and

43 Nigerian cases suggest that admiralty disputes are not arbitrable. See Owners of the MV Lupex $v$ Nigeria Overseas Chartering and Shipping Limited [19931995] NSCC 182; Onward Enterprises Limited v Matrix [2010] 2 NWLR [Pt 1179] 153.

44 Indeed, it has been noted that arbitrability is more vexed in developing countries. See Fiona Campbell, "Arbitrability of Disputes: Issues of Arbitrability Public Policy in the UAE" (Lexology, 28 May 2014) 2 <http://lexology.com/library/ detail.aspx?g =b4e60582-f6aa-435b-8ef0-550b0a9298ce $>$ accessed on 18 August 2018; Muhammed Akanbi, "Contending Without Being Contentious: Arbitration, Arbitrators and Arbitrability" (152nd Inaugural Lecture, University of Ilorin, 13 November 2014) <https://unilorin.edu.ng/UIL/152.pdf> accessed on 18 August 2018; Adewale Olawoyin, "Safeguarding Arbitral Integrity in Nigeria: Potential conflict between Legislative Policies and Foreign Arbitration clauses in Bills of Lading" (2006) 17 The American Review of International Arbitration 239; Chuka Obiozor, "Does an Arbitration clause or Agreement oust the Jurisdiction of the Courts? A Review of the case of the MV Panormos Bay v Olam (NIG) PLC" (2010) 6 Nigerian Bar Journal 165; Ademola Taiwo, "The Effect of Section 20 of the Admiralty Jurisdiction Act No 59 of 1991 on International Arbitration Clauses" (2006) 1 University of Ibadan Law Journal 1.

45 See Muthucumaraswamy Sornarajah, "The UNCITRAL Model Law: A Third World Viewpoint" (1989) 6 Journal of International Arbitration 7, 15-16.

46 See for example, Chinedum Umeche, "Arbitrability of tax disputes in Nigeria" (2017) 33 Arbitration International 1, 4.

47 See generally, Andrew Chukwuemerie, "Arbitration and Human Rights in Africa" (2007) 7 African Human Rights Journal, p. 103. 
uncertain influence of public policy in the determination of arbitrable matters means that parties will be unsure of matters that may be subject to arbitration. ${ }^{48}$ Also, parties in developed countries will be unwilling to enter into an arbitration agreement with their counterparts in Africa because, in the event of enforcement in Africa, an award may be set aside as it may be subject to an adverse interpretation of public policy. This state of affairs holds back the development of arbitration in Africa. ${ }^{49}$ Brief examples of how national statutes and case law in Africa have "protectively" guided arbitrable matters through public policy illustrate this point.

Section 4(2) of the Zimbabwe Arbitration Act 1996 lists matters that are not arbitrable in Zimbabwe. They include matters relating to public policy, although the criteria for determining public policy are not set out. The list also includes matters relating to crime, marriage, and consumer contracts. Although the last two matters may be referred to arbitration by leave of the court, the first two matters (public policy and crime) permit courts to widely interpret public policy. Other African countries with similar arbitration statutes include Liberia, ${ }^{50}$ Botswana, ${ }^{51}$ Tunisia, ${ }^{52}$ Zambia, ${ }^{53}$ and Ghana. ${ }^{54}$

However, statutes in countries like Nigeria and Kenya do not stipulate non-arbitrable matters. ${ }^{55}$ In effect, case law independently

48 Indeed, it has been noted that "business activity is facilitated by legal certainty... The content of any particular law can only be understood in a meaningful way if its application to particular circumstances can be predicted". See Iain MacNeil, "Uncertainty in Commercial Law" (2009) 13 The Edinburgh Law Review, pp. 68, 69.

49 Okereife agrees with this proposition. See Andrew Okekeifere, "Public Policy and Arbitrability Under the Uncitral Model Law" (1999) 2 International Arbitration Law Review, pp. 70, 73.

50 The Liberia Commercial Code Ch 7 (2010) art 7.2 (3) ("non-arbitrable matters" include those "involving the determination of liability for the commission of a crime, a tort, environmental pollution or matters relating to the public interest or the Constitution").

51 Botswana Arbitration Act,1959, s 7.

52 Tunisian Arbitration Code (Law No 93-42 of 26 April 1993), art 7(1).

53 Zambia's Arbitration Act [No19 of 2000], s 6 (2) (a).

54 Alternative Dispute Resolution Act 2010 (Act 978) (the Act applies to all matters except those that relate to (a) the national or public interest; (b) the environment; (c) the enforcement and interpretation of the Constitution; or (d) any other matter that by law cannot be settled by an alternative dispute resolution method).

55 Section 35 of the Arbitration and Conciliation Act, Cap A18, Laws of the Federation of Nigeria 2004 merely provides that the Act will not apply to disputes that may not be submitted to arbitration. 
determines arbitrability in these countries. The Supreme Court of Nigeria stated that matters that are not arbitrable in Nigeria include indictment for an offence of a public nature; disputes arising from an illegal contract, gaming and wagering; disputes leading to a change of status such as divorce petition, bankruptcy proceedings, and winding up a company; and any arbitral agreement that empowers the arbitrator to give a decision in property. ${ }^{56}$ Also, in Kenya, non-arbitrable matters have been held to include contracts "inconsistent with the constitution or other laws of Kenya, whether written or unwritten; or inimical to the national interest of Kenya; or contrary to justice and morality". ${ }^{57}$

The determination of arbitrability through case law particularly generates peculiar difficulties because it allows the courts to exercise uncircumscribed discretion. This section examines cases where courts in Africa interpreted arbitrability, especially through the public policy lens. For reason of space, this article analyses cases in Nigeria, Uganda, and Ghana. Although the case studies do not represent the state of things in all African countries, they indicate a trend in Africa. ${ }^{58}$

\subsection{Nigeria}

In Shell Nigeria Exploration and Production Ltd v Federal Inland Revenue Service and Anor, decided in 2016,59 the appellants (or contractors) entered into a production sharing contract (PSC) with the Nigerian State Oil Company (NNPC) in respect of Deep Offshore Mining Lease (OML) 118. By the PSC, any crude oil found is allocated to the parties in accordance with the "lifting allocation" on the basis of "Royalty Oil", "Cost Oil", "Tax Oil", and "Profit Oil", respectively. The PSC also provided that the contractors shall have the sole right and responsibility to compute the lifting allocation. Subsequently, the contractors alleged that NNPC had breached the terms of the PSC by lifting crude oil in excess of its allotted entitlements. The contractors also alleged that their tax obligations arising under the PSC, contained in the tax returns filed by NNPC with the Nigerian tax authority, Federal Inland Revenue

56 See Kano State Urban Development Board v. Fanz Construction CO [1990] 4NWLR (Pt 142).

57 Christ for all Nations $v$ Appollo Insurance Co Ltd [2002] 2 EA 366.

58 This article identifies the need for a comprehensive comparative study of cases relating to arbitrability in Africa. The choice of countries examined in this article is influenced by recent court decisions and geographical considerations.

59 Unreported Judgment CA/A/208/2012 delivered on 31 August 2016. 
Service (FIRS), were allegedly grossly overstated, and had led to overpayment of tax. Accordingly, and in compliance with the dispute resolution provisions of the PSC, the contractors commenced arbitration proceedings against NNPC, seeking for declarations and reliefs, inter alia, that: under the PSC, the contractors were entitled to compute and allocate tax oil on the basis of their prepared returns under the Petroleum Profit Tax (PPT) Act, and that NNPC should be restrained from submitting tax returns and making tax payments that are inconsistent with the contractor's returns.

Upon receiving information of the arbitration, the Nigerian Federal Inland Revenue Service (FIRS), an agency charged with the statutory functions and powers to assess, collect, and account for taxes under the various tax legislations in Nigeria, took out an Originating Summons at the Federal High Court, Abuja (Nigeria's Federal Capital Territory), citing both the contractors and NNPC as defendants. It sought declarations, inter alia, that the contractor's claims before the arbitral tribunal is not arbitrable, as the determination of such claim will impinge on FIRS' statutory powers, and that the reference of claims that touch on taxation, (a subject matter exclusively reserved for the Federal High Court under Section 251(1) of the Constitution of the Federal Republic of Nigeria 1999) is unconstitutional, null and void. The Federal High Court upheld the position of FIRS and terminated the arbitration proceedings. Dissatisfied, the contractors appealed to the Court of Appeal.

There, they argued that the claims before the arbitral tribunal are purely contractual disputes arising under the parties' contract (the PSC), and are, therefore, arbitrable. They further contended that in any event, the issues relating to computation of Petroleum Profit Tax were only ancillary reliefs in the course of the determination of the private contractual rights of the parties under the PSC. The Court of Appeal rejected this submission. The Court held that a production sharing contract that includes clauses relating to tax issues are not arbitrable because the Federal High Court of Nigeria exclusively adjudicates tax disputes. ${ }^{60}$ This decision affirmed the Court of Appeal's earlier decision

60 See section 251 of the Nigerian 1999 Constitution. The court also relied on section 35 of the Nigeria's Arbitration and Conciliation Act, Cap A18, Laws of the Federation of Nigeria 2004 which provides that the Act "...shall not affect any other law by virtue of which certain disputes - (a) may not be submitted to arbitrations; (b) may be submitted to arbitration only in accordance with the 
in Statoil (Nigeria) Limited and Anor v Federal Inland Revenue Service, ${ }^{61}$ that contracts arising out of tax matters are not arbitrable in Nigeria.

These decisions elicit a question: are all disputes over which the Federal High Court has exclusive jurisdiction non-arbitrable in Nigeria? A commentator agrees with the court that the answer is in the positive. ${ }^{62}$ The effect of this interpretation is that all matters under section 251(1) including energy, oil, and gas, telecommunication, aviation, bankruptcy and insolvency disputes, are inarbitrable. However, the opening paragraph of section 251(1) of the Nigerian Constitution betrays this interpretation. Section 251(1) states: "[n]otwithstanding anything to the contrary contained in this Constitution and in addition to such other jurisdiction as may be conferred upon it by an Act of the National Assembly, the Federal High Court shall have and exercise jurisdiction to the exclusion of any other court in civil matters".

An arbitral tribunal is not a court in Nigeria. ${ }^{63}$ Therefore, section 251(1) of the Constitution cannot be an ouster clause for arbitrable matters. Indeed, the United States' Mitsubishi case noted that in international commercial arbitration, courts ought to exercise a parallel jurisdiction to arbitration tribunals. Therefore, general ouster clauses like 251 (1) of the Nigerian Constitution should not determine arbitrable matters because it regulates court qua court jurisdiction. The Australian Courts rejected this general ouster clause in Rinehart $v$

provision of that or another law". The debate whether tax issues are arbitrable is outside the scope of this article. However, for an analysis, see Thomas Carbonneau \& Andrew Sheldrick, "Tax Liability and Inarbitrability in International Commercial Arbitration" (1992) 23 J Transnational Law \& Policy 1.

61 [2014] LPELR-23144 (CA); See also Nigerian Agip Exploration Ltd $v$ NNPC [2014] 6 CLRN 150.

62 Paul Obo Idornigie, "Nigerian Telecommunications Plc. $v$ Pentascope International B V Private Ltd; Separability Circumscribed by Arbitrability" (2005) 71 Arbitration 372.

63 Section 6(5) of the Nigerian 1999 Constitution. Courts include the Supreme Court of Nigeria, the Court of Appeal, the Federal High Court, the High Court of the Federal Capital Territory, Abuja, a High Court of a State, the Sharia Court of Appeal of the Federal Capital Territory, Abuja, a Sharia Court of Appeal of a State, the Customary Court of Appeal of the Federal Capital Territory, Abuja, a Customary Court of Appeal of a State. See Sunday Ufombo v Wosu Ahuchaogu \& ors (2003) 6 SCM 189. See also Ademola Gbamgbose, "Towards a Suitable Domestic Arbitration Practice in Nigeria" (DPHIL, University of Warwick School of Law 2016), p.104. 
Walker $^{64}$ and Tanning Research Laboratories Inc. $v$ O'Brien ${ }^{65}$ where they held that blanket ouster generalization cannot bar matters that are arbitrable.

A commentator justified the Nigerian Courts' position on the ground that tax disputes are generally contrary to public policy and are, therefore, non-arbitrable. ${ }^{66}$ This study argues otherwise. Contract disputes arising out of tax issues must be severable from general revenue or tax issues. ${ }^{67}$ The principle of "contract separability" should be applied to all issues subject to international commercial arbitration. ${ }^{68}$ On a cursory interpretation of the facts of the case, the issue is purely contractual - it is a case of NNPC's unilateral preparation of tax returns, contrary to the PSC. It is not a case of an aggrieved person against tax assessment or demand notice issued by FIRS under the FIRS Act. Thus, the contractor is not aggrieved by the decision of FIRS; it is contesting NNPC's breach of contract. If the contractor was aggrieved by FIRS' tax computation, it would have triggered the provisions of paragraph 13(1) and 17(1) of the 5th Schedule to the FIRS (Establishment) Act which provides that an aggrieved person can submit tax assessment disputes to a Tax Administration Tribunal, and if dissatisfied with the Tribunal's decision, to the Federal High Court. ${ }^{69}$

Therefore, flowing from the interpretation of the FIRS (Establishment) Act above, the Court of Appeal's invocation of Federal High Court's Jurisdiction is premature. This is because sections 26 and 27 of the FIRS Act provide that tax assessment is based on the tax returns filed by individuals or companies. If the return does not meet FIRS' requirements, FIRS can ask for a fuller and comprehensive tax return to assess the payable tax. It is the dispute arising from the

64 (2012) 95 NSWLR 221.

65 (1990) 169 CLR 332.

66 Chinedum Umeche (n 46) 4.

67 See for example, AED Oil Limited $v$ Puffin FPSO Limited [2009] VSC 534; Petrola Hellas $v$ The Greek State (Award) (1978) 11 Yearbook Commercial Arbitration 105; Lauren Waveney Brazier, "The Arbitrability of Investor-State Taxation Disputes in International Commercial Arbitration" (LLM, University of Wellington 2013); Therese Jansson, "Arbitrability Regarding Patent Law - An International Study" (LLM, Lund University 2010).

68 See Philip Landolt, "The Inconvenience of Principle: Separability and Kompetenz-Kompetenz" (2013) 30 Journal of International Arbitration, pp. 511-530.

69 Federal Inland Revenue Service (Establishment Act), 2007. 
assessment that qualifies as a tax dispute which must be submitted to Tax Appeal Tribunal and/or Federal High Court.

In effect, there is no nexus between the question of who is to file tax returns under the PSC and assessment of tax returns under the FIRS Act. Had the Court of Appeal separated these two issues, maybe it would have come to a different conclusion. Although the English Court in RBRG Trading $v$ Sinocore International held that the degree of connection between the claim and the public issue is an important consideration in determining arbitrable matters ${ }^{70}$ in the Shell case discussed, there was no public element that arises from the dispute as to who should file tax returns under the production sharing contract. While acknowledging that English authorities are only persuasive to Nigerian courts, the latter can take a cue from this English decision. ${ }^{71}$ This is because "[t]he present unduly and restrictive approach of [Nigerian] courts is completely at odds, and does not reflect the growing judicial pragmatism of their counterparts in developed jurisdictions". ${ }^{72}$

Similarly, in Nigerian Telecommunications Plc $v$ Pentascope International BV Private Ltd, ${ }^{73}$ the Nigerian High Court held that where a contract is tainted with illegality, the whole contract (container contract and arbitration agreement) is intertwined with public policy; hence, the dispute is non-arbitrable. In this case, the company, without being incorporated in Nigeria as mandated by section 54(1) of the Companies and Allied Matters Act, ${ }^{74}$ entered into a contract, which was the subject matter of dispute. The Plaintiff argued that the contract, together with the arbitration agreement, is void for non-compliance with the Companies and Allied Matters Act. The Plaintiff also argued that once the validity of a contract is raised, the court must decide this issue, and not refer it to arbitration. The Court agreed with these

70 [2018] EWCA Civ 838. See also Patel v Mirza [2016] UKSC, p.42.

71 Indeed, the Australian Court in TLC Air Conditioner (Zhongshan) $v$ Castel Electronics Pty Ltd (2014) 232 FCR 361 383-384 advises that: “... it is not only appropriate, but essential, to pay due regard to the reasoned decisions of other countries where their laws are either based on, or take their content from, international conventions or instruments such as the New York Convention and the Model Law".

72 Taofeek Alatise, "Stay of Proceedings Pending Arbitration: Protecting the Interests of Third-Parties to Arbitration in Nigeria" (2018) 9 Afe Babalola University Journal of Sustainable Development Law and Policy 220, 241.

73 Suit No FHC/ABJ/CS/36/2005 delivered on 25 May 2005.

74 Cap C20 Laws of the Federal Republic of Nigeria 2004. 
arguments and declined the application to stay proceedings pending arbitration.

Again, I disagree with the Plaintiff's argument and the court's position. This is because, without evidence, the court presumed that the contract is shrewd with illegality. ${ }^{75}$ The determination of illegality in a contractual dispute, is at best, a matter of mixed law and fact, which ought to be left for the arbitral tribunal to decide. ${ }^{76}$ Indeed, the Canadian Supreme Court held that where the issue to be decided in a container contract is a matter of a mixed question of law and fact, the container contract, together with the arbitration agreement - which is treated separately-ought to be referred to arbitration. ${ }^{77}$ This approach supports a pro-arbitration policy where the container contract and arbitration agreement are treated separately.

However, Idornigie argues that where public policy is in issue, the doctrine of separability must give way. ${ }^{78} \mathrm{He}$ argues that this is expedient and cost-saving because the issue of arbitrability and legality of the container contract is resolved in only one forum - the court. However, this argument neglects the fundamental principle upon which an arbitral

75 This is contrary to the principle of implied consent to arbitrate. See Alan Scott Rau, "Everything You Really Need to Know About 'Separability' in Seventeen Simple Propositions" (2003) 14 American Review of International Arbitration 1, 34-35 ('The thrust of the doctrine of 'separability, then, is to recognize the probable competence of the arbitrators, by presuming that they have been entrusted by the parties with the power to make a virtually non-reviewable decision on the issue of validity"). See also Richard Reuben, "First Options, Consent to Arbitration, and the Demise of Separability: Restoring Access to Justice for Contracts with Arbitration Provisions" (2003) 56 S M U L Rev 819; Francis Okanigbuan Jr, "Revisiting the Separability Doctrine and Parties' Rights to Litigation in Commercial Transactions" (2015) 26 International Company and Commercial Law Review, p.255.

76 See Peter Gillies, "Enforcement of International Commercial Arbitration Awards - the New York Convention" (2004) 9 International Trade and Business Law Review, pp.19, 23-25.

77 Dell Computer Corp v Union des Consommateurs [2007] 2 SCR 801.

78 Paul Obo Idornigie (n 62) 377. He notes that “...if the contract is in law not subsisting, even if the principle of separability is applied the principle cannot stand in vacuum as it requires a platform to treat the liability arising from the breach of the underlying contract to which the terms of the contract relate. What the principle of separability states is that the arbitration clause is independent of the other terms of contract. It does not mean it is independent of the contract... the principle of separability is circumscribed by the principle of arbitrability". 
agreement is based - party autonomy. It is also against the principle of kompetenz-kompetenz because it assumes that an arbitrator has no competence to rule on its own jurisdiction. ${ }^{79}$ Furthermore, compared to courts, one of the advantages of arbitration is its speed. Therefore, the jurisdiction of the arbitration tribunal can be taken at the tribunal's preliminary hearing and decided expeditiously. ${ }^{80}$ Indeed, the argument that it is expedient for courts to determine arbitrability was rejected in the recent decision of the US Supreme Court in Henry Schein, Inc. $v$. Archer \& White Sales, Inc. ${ }^{81}$ The Supreme court held that where a Court thinks that it is groundless to refer issues of arbitrability to an arbitration panel, the court must still respect parties' wish.

Similar to Idornigie position, Onyema noted that “...in the context of Nigerian law where the subject matter of the underlying contract is not arbitrable, then both the main contract and arbitration agreement contained in it will be void for illegality or on the grounds of public policy". ${ }^{82}$ This position opposes recent global contemporary developments in arbitration. ${ }^{83}$ Indeed, it has been noted that "in

79 Idornigie's argument assumes that the arbitrator has no jurisdiction to rule on illegality. This position is incorrect, courts have upheld arbitral panels' ruling on illegality, if they are satisfied that the arbitral panel applied the law to the facts and there is no miscarriage of justice. The English court in Fiona Trust \& Holding Corp $v$ Privalov [2007] Lloyd's Rep 267 held that fraud and corruption can be decided by the arbitral tribunal; see also the United States' decision in Meadows Indemnity Co $v$ Baccala \& Shop Insurance Services, 760 F Supp 1036 (1991) where it was held that issues of fraud are arbitrable. The French court in Cour d' Appeal de Paris, 29 March 1991 and Ganz and Others $v$ Soc Nationale des Chemins de fer Tunisiens REY ARB [1991] 478 arrived at a similar decision.

80 Harry Edwards, "Advantages of Arbitration over Litigation: Reflections of a Judge" (1983) Proceedings of the 35th Meeting of the National Academy of Arbitrators 16, 23.

81586 US 139 S Ct. 524 (2019).

82 Emilia Onyema, "The doctrine of Separability under Nigerian Law" (2009)1 Apojee Journal of Business, Property and Constitutional Law, pp.65, 74.

83 See for example, Article 1458 of the French New Code of Civil Procedure (1981) which provides that "Whenever a dispute submitted to an arbitral tribunal by virtue of an arbitration agreement is brought before the court of the state, such court shall decline jurisdiction. If the arbitral tribunal has not yet been seized of the matter, the court should also decline jurisdiction unless the arbitration agreement is manifestly null". See also Société Nationale Algerienne pour la Recherche, la Production, le Transport, la Transformation et la Commercialisation des Hydrocarbures $v$ Distrigas Corporation 80 BR 606, 612 (1987) (The US Court held that "allowing an arbitration clause to be automatically invalidated along with the principal agreement would be akin to destroying precisely what 
conjunction with the acceptance of the doctrine of separability it has become increasingly accepted that allegations of the illegality of the main contract do not automatically lead to the non-arbitrability of the dispute". ${ }^{84}$

If Onyema's position is correct, then, upon termination or completion of a contract, the arbitration agreement will naturally end with the contract. This article demonstrates that an arbitration agreement must survive the contract because it is the basis upon which claims or counterclaims arising from the contract are settled..$^{85}$ Onyema's position reflects the English court's decision in Hirji Mulji $v$ Cheong Yue Steamship Co Ltd decided in $1926 .{ }^{86}$ The English court of appeal held that frustration of a contract ends the whole contract, including the arbitration clause. However, English courts have moved away from this position since 1942; they now extend the principle of separability to the initial illegality of the contract. For example, in Heyman $v$ Darwins $L t d,{ }^{87}$ the court held that if the general purpose of the contract fails, the arbitration clause is not one of the purposes of the contract, hence, it survives the contract. ${ }^{88}$ In sum, this article argues that, contrary to

the parties had sought to create as a dispute resolution device"); Twi Lite International Inc $v$ Anam Pacific Corp 1996 WL637843 (ND Cal).

841 Loukas Mistelis, "Legal Issues Arising out of Disputes Involving Fraud, Bribery, Corruption and Other Illegality and Illicitness Issues" in Emmanuel Gaillard \& Domenico Di Pietro (eds), Enforcement of Arbitration Agreements and International Arbitration Awards: The New York Convention in Practice (Cameron May 2008) 573, 585. See also Pierre Mayer, "Effect of International Public Policy in International Arbitration?" in Loukas Mistelis \& Julian Lew (eds), Pervasive Problems in international Arbitration (Kluwer 2006), p.61.

85 See Alan Rycroft (n 37) 22. See also John Pottow, Jacob Brege \& Tara Hawley, "A Presumptively Better Approach to Arbitrability" (2013) 53 The Canadian Business Law Journal 165.

86 [1926] AC 497.

87 [1942] App Cas 356; see also Harbour Assurance Co. Ltd. v Kansa General International Insurance Co. Ltd [1993] 1 Lloyd's Rep 455.

88 See also United States' decisions in Prima Paint Corp v Flood \& Conklin Manufacturing Corporation 388 U S 395 (1967) (holding that the dispute must be referred to arbitration unless the challenge is to the arbitration clause itself); Buckeye Check Cashing Inc v Cardegna 126 S Ct 1204 (2006) ("Regardless of whether it is brought in federal or state court, a challenge to the validity of a contract as a whole, and not specifically to the arbitration clause within it, must go to the arbitrator, not the court"). See Kirsten Weisenberger, "From Hostility to Harmony: Buckeye Marks A Mile-stone in the Acceptance of Arbitration in American Jurisprudence" (2005) 16 American Review of International Arbitration 551, 558; John Pottow, Jacob Brege, \& Tara J Hawley, "A Presumptive Better 
Idornigie and Onyema's positions, the doctrine of separability should not be circumscribed by arbitrability. ${ }^{89}$

\subsection{Uganda}

Similar to cases in Nigeria, the High Court of Uganda in Heritage Oil and Gas Ltd $v$ Uganda Revenue Authority, ${ }^{90}$ revoked an arbitration clause in a Production Sharing Agreement because the container agreement relates to tax matters. Article 14 of the PSA (container contract) provides that: "[a]ll central, district, administrative, municipal and other local administrators or other taxes, duties, levies or other lawful impositions applicable to licensee shall be paid by the licensee in accordance with the laws of Uganda in a timely fashion". Article 26.1 of the PSA, which contains the arbitral clause, provides that: "[a]ny dispute arising under the Agreement, which cannot be settled amicably within sixty (60) days shall be referred to Arbitration in accordance with the United Nations Commission on International Trade Law (UNCITRAL) Arbitration Rules...The Arbitration award shall be final and binding on the Parties to this Agreement." The High Court of Uganda held that only the Uganda Revenue Agency (URA) can collect tax in Uganda. Therefore, the container contract, together with the arbitration agreement, is void because parties cannot contract out of a statute.

It is trite that an arbitral clause does not oust the jurisdiction of courts, but it puts the rights of parties in abeyance, pending the conclusion of arbitration proceedings. ${ }^{91}$ The court closed its eyes to this principle; instead, it presumed against arbitration. ${ }^{92}$ In a manner

Approach to Arbitrability" (2013) 53 The Canadian Business Law Journal 178 (“... the approach in the United States is now one of strong arbitrability: it is almost impossible to plead a claim of contractual infirmity that will be heard by a court").

89 The separability doctrine is important in international arbitration to be circumscribed by issues of arbitrability. Indeed, Okanigbuan Jnr points out the importance of separability doctrine when he notes that "[t]he application of the [separability] doctrine checks the excesses of parties who may intend to frustrate or delay the enforcement of the contract by a reference to national courts that the contract embodying the agreement of the parties was void." See Francis Okanigbuan Jr (n 74) 259.

90 (Civil Appeal No 14 of 2011) [2011] UGCOMMC 97 (12 September 2011).

91 Scott $v$ Avery (1856) 5 H L C 811.

92 The Judge noted: "I am of the opinion that this article [Article 14] of the PSA also implied that any dispute relating to payment of those taxes would be resolved in accordance with the laws of Uganda. This is because the mechanism for tax dispute resolution in Uganda is explicit under the ITA and TAT Act". 
that reflects a narrow nationalist policy approach, the court held that since article 14 of the PSA imposes taxes on the licensee according to the laws of Uganda, such matters are generally not arbitrable. The rationale is that "[taxation] is the most reliable source of funds for most developing economies and therefore subjecting it to the whims and negotiation skills of contractors and Government Officials would create uncertainty and inequity on the amounts payable and cause economic instability". ${ }^{93}$

The High Court missed the point in this case. Article 14 only imposed duties on the licensee according to taxation laws in Uganda. It did not subject the container contract to Ugandan law. In any event, the arbitral clause, which is separable from the container contract, refers to the resolution of disputes in accordance with the UNCITRAL Model Rules. The combined provisions of Article 1 and 23 of the UNCITRAL Rules mandate recourse to the arbitral tribunal to determine its own jurisdiction. ${ }^{94}$ Moreover, there was an ongoing arbitral proceeding in London. The choice of London as the seat of arbitration shows that the parties intended that English law should apply. This is because "[i]f a contract contains a general choice of law clause and provides in the arbitral clause that arbitration is to be held in a country with a different law, the latter indication must be deemed to prevail over the former". ${ }^{95}$

The court neither considered the UNCITRAL Rules nor the law of the seat of arbitration. It may be argued that even if the court had

93 At page 19.

94 Article 1 of the Revised UNCITRAL rules (2010) provides that "Where parties have agreed that disputes between them in respect of a defined legal relationship, whether contractual or not, shall be referred to arbitration under the UNCITRAL Arbitration Rules, then such disputes shall be settled in accordance with these Rules subject to such modification as the parties may agree." Article 23 provides that: "Arbitral tribunal shall have the power to rule on its own jurisdiction, including any objections with respect to the existence or validity of the arbitration agreement. For that purpose, an arbitration clause that forms part of a contract shall be treated as an agreement independent of the other terms of the contract. A decision by the arbitral tribunal that the contract is null shall not entail automatically the invalidity of the arbitration clause".

95 Albert Jan van den Berg, The New York Arbitration Convention of 1958: Towards a Uniform Judicial Interpretation (Kluwer Law and Taxation 1981) 293. See also Gary Born, International Commercial Arbitration (2nd ed, Kluwer 2014) § 25.04[A], 3203 ("The default rule is very clearly the law of the arbitral seat, not the law governing the parties' underlying contract"). 
considered these issues, it would have struck down the arbitral agreement because the agreement is against Uganda's public policy. However, this argument cannot be taken seriously because, as pointed out above, the container contract subjects the licensee to the tax laws in Uganda. Therefore, the arbitral tribunal will interpret duties and obligation arising from the contract according to the taxation law in Uganda. Even if the tribunal fails in its duty, the court's supervisory function is not foreclosed - it can review the award at the enforcement stage for any breach of Uganda's public policy. It may be safe to conclude that the court was not comfortable with the ongoing arbitral proceedings in London because of the tribunal's perceived threat to Uganda's economy. Therefore, it looked for a way to halt the tribunal in its steps.

\subsection{Ghana}

Much like its neighbours in Nigeria and Uganda, the Ghanaian Supreme Court, in Attorney-General v Balkan Energy LLC \& Ors, decided a case between a foreign energy company and the government of Ghana. ${ }^{96}$ The issue was whether the Power Purchase Agreement (PPA) - the contract that is the subject of arbitration - and the arbitral clause requires Ghana's parliamentary approval. ${ }^{97}$ Although Ghanaian law is that the PPA is the governing law, ${ }^{98}$ the arbitral clause was to be governed by the UNCITRAL Rules and the seat of arbitration was the Netherlands. ${ }^{99}$ Notwithstanding that the Supreme Court acknowledged that the arbitral clause is a separate contract that does not require parliamentary approval, it held that since an international commercial arbitration draws its life from the container contract, the arbitral clause is not separate and independent from the container contract.

96 Attorney-General v Balkan Energy LLC \& Ors [2012] 2 SCGLR 998.

97 ibid. See section 181 (5) of the Ghanaian 1992 Constitution which stipulates that all international business or economic transaction(s) to which the Government is a party should be submitted to Parliament for approval.

98 Article 23 of the PPA provides that: "[t]his Agreement shall be governed by and construed in accordance with the laws of the Republic of Ghana".

99 Article 22 of the PPA provides that "If any dispute arises out of or in relation to this Agreement and if such matter cannot be settled through direct discussions of the Parties, the matter shall be referred to binding arbitration at the Permanent Court of Arbitration, Peace Palace, Carnegieplein 2, 2517 KJ in The Hague, The Netherlands. ... Applications may be made to such court for judicial recognition of the award and/or an order of enforcement as the case may be. Arbitration shall be governed by and conducted in accordance with UNCITRAL rules". 
In effect, the court held that the container contract and arbitral clause are inextricably linked, such that the fate of the former must befall the latter. ${ }^{100}$ Indeed, this argument was advanced by one of the experts retained by the Government of Ghana at the award's enforcement proceedings in the United States' District Court of Columbia. ${ }^{101}$ The District Court rejected the argument. ${ }^{102}$ It separated the arbitration agreement from the container contract and held the Ghanaian government liable. Expectedly, the Ghanaian government also argued that the award was contrary to United States' public policy under Article V(2)(b) of the New York Convention because the PPA is invalid under Ghanaian law. The District Court noted that although the public policy defence is frequently raised, it is rarely successful. ${ }^{103}$ The Court, therefore, held that the public policy defence under Article $\mathrm{V}(2)(\mathrm{b})$ is to be construed narrowly and is available only where an arbitration award "tends clearly to undermine the public interest, the public confidence in the administration of the law, or security for individual rights of personal liberty or of private property". ${ }^{104}$ Since the

100 For analysis of the shortcomings of this approach, see generally, Danika Balusik, "Enforcement of Foreign Arbitral Awards in Africa: An Analysis of the Regime in South Africa and Ghana" (Lexology, 2 April 2019) < https://lexology.com/ library/detail.aspx?g=e5501fd4-da44-40ac-be96-9320273097ed $>$ accessed on 22 April 2019.

101 Balkan Energy Limited, et Al v Republic of Ghana Case No. 17-cv-00584(APM) delivered on 22 March 2018 < https://us-arbitration.shearman.com/siteFiles/ 21504/2018.03.22\%20BALKAN\%20ENERGY\%20LIMITED\%20et\% 20al\%20v.\%20REPUBLIC\%20OF\%20GHANA,\%20No.\%201_17-cv....pdf> accessed on 18 August 2018.

102 It relied on Belize ( $\mathrm{n}$ 24) to reach this conclusion. Belize has a similar case fact to the present case. In Belize, the government of Belize argued that its former prime minister lacked capacity to enter into the contract, and as a result, the contract together with the arbitration clause, is void. The District court held that in order to invalidate the arbitral clause, the government of Belize must show that the prime minister lacked capacity to enter into the arbitration agreement itself.

103 At page 22. This is also true for most countries. See George Bermann (ed), Recognition and Enforcement of Foreign Arbitral Awards: The Interpretation and Application of the New York Convention by National Courts, vol 23 (Springer International 2017) 61. ("while the public policy defense may commonly be invoked in national legal systems, it is seldom invoked successfully").

104 Ibid. The public policy objection argument was also raised in Washington DC Court of Appeal's between Enron Nigeria Power Holding Ltd $v$ Federal Republic of Nigeria No. 1:13-cv-01106. The Nigerian government contended that the award should be set aside because the contract was fraudulently induced, therefore, contrary to public policy. The Court of Appeal rejected this argument 
Ghanaian government could not show any public interest, the defence was unavailable. The District Court's interpretation of public policy and the doctrine of separability reflects the contemporary approach that this article proposes.

\section{An Overview of African Practice through Morgan's Theoretical Lens}

The cases discussed in this article reflect a blurred distinction between private rights and state interests in courts' determination of arbitrability in Africa. This article, grounded in Morgan's theoretical framework of contractual rights and state interest, opposes such a blurred distinction. ${ }^{105}$ Morgan argues that in the determination of arbitrable issues, courts must distinguish between those rights that naturally flow from one person's interaction with another and those that are imposed by the state in furtherance of the collective interest. ${ }^{106}$ If the cases examined in this article are subjected to Morgan's theoretical framework of analysis, it shows that some courts in Africa have trumped state interest over personal autonomy because of their reluctance to fully embrace the doctrines of party autonomy, separability, kompetenzkompetenz, which are the cornerstones of thriving arbitration practice.

Notwithstanding the foregoing criticism, this article does not argue that there is no prospect for a thriving international arbitration practice in African countries. Indeed, there are some decisions in Africa that reflect global trends on arbitrability. For example, the Kenyan High Court in Jatin Shantilal Malde \& 9 others $v$ Transmara Investment Limited $\& 2$ others ${ }^{107}$ suggests that if a constitutional interpretation is intertwined with a private dispute, Kenyan Courts will lean towards resolving the

on the basis that that enforcement of the award is not so manifestly unjust that its confirmation would "undermine . . . the public confidence in the administration of the law"; similar arguments were made in Abuja International Hotels $v$ Meridian SAS [2012] Lloyd's Rep but it was rejected under sections 67 and 68 of the United Kingdom Arbitration Act 1996. It should be noted that these cases were decided under the United States and English law respectively. They may be decided differently in Nigeria.

105 Edward Morgan, "Contract Theory and the Sources of Rights: An Approach to the Arbitrability Question" (1987) 60 Southern California Law Review, p. 1059.

106 ibid 1075 ("claims premised on interpersonal impingement can readily be removed from judicial administration, since the rights at stake in such disputes can trace their roots to a conception of the parties' autonomy").

107 (Petition No 18) [2018] eKLR. 
private dispute without making pronouncements on the constitutional issue, if the dispute can be resolved on the private issues alone. Therefore, the arbitral jurisdiction is preserved because the court will bifurcate public and private issues to grant a stay of court proceedings pending arbitration.

\section{RECOMMENDATIONS FOR ALIGNING WITH GLOBAL BEST PRACTICES}

As international contractors and consultants engage with the states, state entities and domestic contracting firms (as sub-contractors) in the ever-increasing market for major infrastructure projects in developing countries, the need for an efficient framework for the effective resolution of disputes from transnational commercial transactions has become even more acute. ${ }^{108,109}$ Countries in Africa cannot rely on litigation to resolve disputes arising from these relationships, hence, the resort to arbitration as a means of alternative dispute resolution. However, clutching to a nationalistic, protective and narrow interpretation of public policy in relation to arbitrability will slow down the development of arbitration practice in Africa. Indeed, Africa has its peculiar challenges to arbitration. Adding restrictive interpretations will deepen these challenges. ${ }^{110}$ Interpretational challenges relating to arbitrability in international commercial transactions will make some African countries unfriendly to arbitration. This is because "arbitrability has the potential to affect the validity of an arbitration agreement, strip an arbitrator of jurisdiction, or derail enforcement of an award". ${ }^{111}$ As a result, Africa may remain an unsuitable region for arbitration, even if its traditional challenges are solved. Solutions must come from judicial and legislative as well as regional efforts in Africa. I explain these heads in turn.

108 Saul Perloff, “Ties that Bind: The Limits of Autonomy and Uniformity in International Commercial Arbitration" (1992) 13 University of Pennsylvania Journal of International Business Law 323.

109 Mante (n 11).

110 These challenges can be termed "Afro-centric" challenges. They include lack of professional interaction, lack of diversity, proliferation of regional arbitration centers, language and territorial Barriers, the African cultural context, corruption and lack of experience. See Paul Ngotho, "Challenges Facing Arbitrators in Africa" (East Africa International Arbitration Conference, Nairobi, 28 July 2014].

111 Mante (n 11) 1. 


\subsection{The Judicial Task through a Proactive Approach}

African countries must "catch-up" with their counterparts in other regions through a narrow interpretation of public policy, loyalty to the doctrine of kompetenz-kompetenz, and severability in international commercial arbitration. ${ }^{112} \mathrm{~A}$ proactive judicial approach should be based on current best practices and global trend, as this is a viable means to reduce the influence of public policy on questions of arbitrability in Africa. ${ }^{113}$ This is because "discovering the 'actual prohibition of the law,' which constitutes the public policy exception, is an interpretive and judicial task". ${ }^{114}$ Through a proactive judicial approach, the prospect of a uniform interpretation of the Model Law and the New York Convention may be enhanced.

This article does not recommend that courts in Africa copy judicial interpretation wholesale from other regions. Neither does it advocate for a total and uniform global interpretation. Rather, it argues that courts in Africa must create their distinctive approach to uniform interpretation on arbitrability that considers Africa's historical, political and economic past and the realism that modern best practices capture in regard, particularly, to the socio-economic contexts for the application of arbitration laws to international commercial disputes. In effect, this article argues for substantial, and not total uniformity because it has been noted that "in an ideal world, a uniform interpretation would be desirable...[however]....an attempt to determine arbitrability through [a] uniform interpretation of the New York Convention would be, in practice, utopian". ${ }^{115}$

112 See generally, Onyema (n 80); Ronan Feehily, "Separability in International Commercial Arbitration; Confluence, Conflict and the Appropriate Limitations in the Development and Application of the Doctrine" (2018) 34 International Arbitration 355; Jack Tsen-Ta Lee, "Separability, Competence-Competence and the Arbitrator's Jurisdiction in Singapore" (1995) 7 Singapore Academy of Law Journal 421; Ozlem Susler, "The English Approach to CompetenceCompetence" (2013) 13 Pepperdine Dispute Resolution Law Journal 415; Leonardo de Oliveira, "The English Law Approach to Arbitrability of Disputes" (2016) 19 International Arbitration Law Review 155.

113 See for example, Andrew Tweedale, "Enforcing Arbitration Awards Contrary to Public Policy in England" (2000) 17 The International Construction Law Review 159.

114 Farshad Ghodoosi, "Arbitrating Public Policy: Why the Buck Should not Stop at National Courts" (2016) 20 Lewis \& Clark Law Review 237, 270.

115 Dorothee Schramm, Elliot Geisinger \& Phillipe Pinsolle, "Article II" in Hebert Kronke et al (eds), Recognition and Enforcement of Foreign Arbitral Awards: A Global Commentary on the New York Convention (Kluwer 2010) 37, 72. 


\subsection{Legislative Reform}

A common theme from the cases analysed in this article is the blurred distinction between a container contract and an arbitration agreement. This has led to a wide interpretation of the public policy to deny arbitral jurisdictions, revoke arbitration clause, and refuse enforcement. If the global trend of separating the container contract from the arbitration agreement, together with recognition of the doctrine of kompetenzkompetenz is applied, public policy will assume a narrow interpretation, as it is done in most jurisdictions today. This global trend is aptly reflected in Article 23 (1) of the UNCITRAL Model Rules which states that:

[t]he Arbitral tribunal shall have the power to rule on its own jurisdiction, including any objections with respect to the existence or validity of the arbitration agreement. For that purpose, an arbitration clause that forms part of a contract shall be treated as an agreement independent of the other terms of the contract. A decision by the arbitral tribunal that the contract is null shall not entail automatically the invalidity of the arbitration clause.

If countries in Africa adopt this piece of legislation, it will enhance the prospect of achieving a uniform interpretation of the UNCITRAL Model Law. ${ }^{116}$ Although the Model Law is only a guide, it is hoped that Article 23 will achieve convergence among African countries and other jurisdictions around the World. South Africa's recent adoption of the Model Law signifies a welcoming development in this regard. However, even if adopted, ${ }^{117}$ the Model law must be supported by progressive judicial interpretation because "even where there is a good law, a judge can make a hell out of it". ${ }^{118}$ In effect, parties will be comfortable to choose an African jurisdiction as the seat of arbitration if they are sure that African countries would apply globalized principles of arbitration,

116 See María Pilar Perales Viscasillas, "Is a Uniform Arbitrability Needed at an International Level?" (Kluwer International, 5 January 2016) < http:// kluwerarbitrationblog.com/2016/01/05/is-a-uniform-arbitrability-ruleneeded-at-an-international-level/ $>$ accessed on 18 August 2018. See also Gerold Herrman, "UNCITRAL Arbitration Law: A Good Model of a Model Law" (1998) 3 Uniform Law Review 483, 490. Herrmann argues that adopting the UNCITRAL Model has a public relations effect.

117 As Nigeria has done with its Arbitration and Conciliation Act (n 60).

118 Alatise Taofeek, (72) 241. 
which include arbitrability. ${ }^{119}$ Some speakers at the Second International Chamber of Commerce Conference held in Kenya, 5 June 2017, on "The Future of Arbitration in Africa: Accommodating Economic Growth and Concomitant Challenges", ${ }^{120}$ recommend that Africa needs a change in culture. Africa needs a change both in law and culture regarding what is arbitrable and how to construe it.

\subsection{Regional Institutional Integration}

The growing arbitration institutions in Africa may achieve global legislative convergence. ${ }^{121}$ For example, the revised Organization for the Harmonization of Business Law in Africa (OHADA) Uniform Act on arbitration and revised Rules of the Joint Court of Justice and Arbitration Act, which entered into force on 15 March 2018, is a step in this direction. The instrument, which is in line with UNCITRAL Model Law and international best practices, binds 17 member states of OHADA. ${ }^{122}$ Although the domestic interpretation of laws among OHADA member states is outside the scope of this article, the OHADA framework may provide a supranational legal blueprint for African countries, particularly the conventional common law jurisdictions.

\section{CONCLUSION}

This article discussed the amorphous nature of public policy and its influence on matters that are arbitrable. It particularly examined courts'

119 See for example Alexander Brabant and Ophélie Divoy, “The Enforcement of International Arbitral Awards in OHADA Member States - The Uniform Act on Arbitration is Not the Smooth Ride it was Designed to Be" (2016)13 TDM Special Edition 1.

120 See the speakers<https://iccwbo.org/event/future-arbitration-africaaccommodating-economic-growth-concomitant-challenges/ > accessed on 18 August 2018.

121 Roland Ziade \& Clement Fouchard, "New OHADA Arbitration Text Enters into Force" (Kluwer International, 30 March 2018) < http://arbitrationblog. kluwerarbitration.com/2018/03/30/new-ohada-arbitration-text-enters-intoforce/> accessed on 17 April 2019.

122 Michael Ostrove, Ben Sanderson \& Andrea Lapunzina Veronelli, "Developments in African Arbitration" (The Middle Eastern and African Arbitration Review, 10 May 2018) < https://globalarbitrationreview.com/benchmarking/themiddle-eastern-and-african-arbitration-review-2018/1169293/ developments-in-african-arbitration> accessed on 10 April 2019. 
difficulty to distinguish between those rights that naturally flow from one person's interaction with another and those that are imposed by the state in furtherance of the collective interest. Through an analysis of selected case studies, it concludes that most countries - especially developed ones - have limited the influence of public policy in the determination of disputes that would be subject to arbitration. However, some courts in African states still take a nationalistic protective approach to public policy influence on arbitrability - they hold that private relationships touching sovereign economic interest, no matter how minute, are non-arbitrable.

Adopting this approach is not in the best economic interest of developing countries because parties from developed countries will not choose an arbitral seat that restricts the scope of arbitrability, nor will they be willing to enter into contracts with parties in these countries. A change in approach must be made to reflect the emergent global practice of restricting the scope of public policy. For Africa, judicial activism, legislative innovation, and regional institutional integration are the ways to utilize to effect this change. Among them, judicial activism is the most potent tool for this purpose because the judges not only interpret existing law and doctrine. As well, they can be forceful in the push for legislative and policy change. It must not be forgotten that ultimately, it is Africa's socio-economic and legal development which hang on this change. 